\title{
GENESIS, DEVELOPMENT AND IMPORTANCE OF PRIVATE SECURITY COMPANIES IN THE PROVISION OF PUBLIC SAFETY IN POLAND
}

\author{
Andrzej CZOP, PhD \\ kcb.aczop@o2.pl \\ Pedagogical University of Cracow
}

\begin{abstract}
The author benefitted from the support of the private security sector as the ChiefOfficer of the City Police. When, after leaving the service, he was the President of the Polish Association of Employers Protection Branch "Matopolska", one of the basic objectives of his activity was to ensure a high level of functioning of the private security sector as an important component of public security. Optimisation of the use of private security companies to ensure public security and order is one of the basic directions of his practical operation and research conducted by him. In the article, the author discusses the role of the private security sector and the tasks set for this sector. The genesis of security companies, their evolution and development in various countries of Europe and the world is covered. Much attention is devoted to the de-monopolisation of security in Poland, in which the security companies played a special role. The author outlines the most important objectives of private sector development in Poland as a specific type of economic activity. The basic concepts related to the functioning of security companies are explained, exposing their priority task, which is the protection of facilities, areas and equipment important for the functioning of the state. The author shows that the current level of terrorist threats implies the need for greater involvement of security companies in providing security to facilities constituting the critical infrastructure of the state. The role of specialist armed security formations in this area is highlighted. In the conducted research process, a positive answer to the main question is given, demonstrating that security companies are currently an important element of the public security system in Poland, and their use in this area should be constantly strengthened.
\end{abstract}

Keywords: private security companies, private security sector, public security, security system 
The author conducts a study of the role of the private security sector in ensuring public security in Poland. He has cooperated with security companies in practice, acting as the Chief Officer of the City Police in Krakow. Despite the lack of precise legal regulations that would regulate the principles of such cooperation, he expressed the conviction that such an important partner should not be underestimated. Hence, he included security companies in security activities and got them involved, especially when organising security for mass events, so he could benefit from their support. After leaving the police, the author became president of the Polish Association of Employers Protection Branch "Małopolska". Representing the private security sector, he undertook intense activities to increase the participation of security companies in the public security system. In this article, the author formulates a research problem contained in the question: Are security companies currently recognised as an essential element of the public security system in Poland?

To find the answer for this basic question, more specific questions were asked: • What was the impact of economic and political changes on the process of the demonopolisation of security?

- Has the private security sector changed over the years?

- Are the tasks of security companies and competences of the employees employed in those companies enough to enable their use in ensuring the security of facilities important for the functioning of the state?

- Does the current level of threats imply the need for greater involvement of security companies in providing security to facilities, constituting the critical infrastructure of the state?

\section{The value of security}

Security is one of the main needs of a human being. Fulfillment of this need is essential to fully enjoy other values, providing the opportunity to survive and develop. In 1942, Abraham Maslow presented a theory indicating that a man during his life presents needs that are built in a hierarchical system: for the most basic, necessary for fulfilling needs, Maslow recognised the physiological (biological), and the next in line is a security need. Only then, greater needs such 
as: belonging, respect or self-respect might be developed. According to Maslow, only a well-organised and efficient society is able to provide its members with a sense of security that will allow them to fulfil the greater needs. As long as the need of security is not met, it is the main goal on which people concentrate their entire life activity. Therefore, security needs are the main factors that organise human behaviour (Maslow 2009, p. 53).

According to the Dictionary of the National Security Bureau, the internal security of the state (national security) is a trans-sectoral area of security whose content (goals, conditions and means) refers to the internal environment of the state (national environment). ((MINI)SŁOWNIK BBN: Propozycje nowych terminów z dziedziny bezpieczeństwa, [15 october 2017] http://www.bbn.gov.pl/pl/ bezpieczenstwo-narodowe/minislownik-bbn-propozy/6035,MINISLOWNIKBBN-Propozycje-nowych-terminow-z-dziedziny-bezpieczenstwa.html). As one of the most important sectors of the internal security interpreted in this way, the authors of the dictionary recognise public security. While, according to J. Widacki and P. Sarnecki, the term "public security" combines the notion of "internal security of the state" and "national security" and indicates: not threatened, correct operation of public structures which function or which act for citizens as well as enforce civic obligations to the state. Therefore, all members of the society are interested in the effective functioning of these structures, as they ensure the fulfillment of their basic needs (Widacki and Sarnecki 1997, pp. 7-15). According to E. Ury, the main beneficiary of public security interpreted in this way is the general public, while public security itself is a condition in which citizens are not threatened by any danger, regardless of the source that can generate it. (Pieprzny 2012. p. 14). The Supreme Court also defines public security, in a judgment issued on December 22, 1993, as: "the whole order and social mechanisms that protect citizens from phenomena dangerous to life, health or the threat of serious losses in the national economy". (Wyrok Sądu Najwyższego z 22 grudnia 1993 , I KZP 30/93, OSNKW, 1994, nr 1-2, poz. 6). 


\section{History and engagement of a private security sector worldwide and in Poland}

The first security companies were established in the United States as early as in the mid-nineteenth century, mainly for the protection of the railway network, developed with enormous dynamics. Until 1918, robbery on a train was treated as a crime of great significance, so-called federal crime. Precursors of the private security sector were such companies as: Well`s Fargo Company, Pinkerton National Detective Agency, and Brinks Incorporated. They appeared due to the ineffectiveness of state authorities, especially of the police, which was unable to ensure the security of large-scale economic undertakings. In 1990, the security service companies in the US employed about 1.5 million people, i.e. three times more than the police. The revenues of these companies in 1980 were twice as high as the expenditure on the police in this country and amounted to 52 billion dollars. This shows how essential an element in the security system of such a large power the private security sector is ([12 september 2017] http://www.Public-policy.org). Interestingly, in most US states, there are no separate legal regulations regarding its functioning (Johnston 1992, p. 79). The situation of the private security sector is somewhat different in the European Union.

In 1988, in France, there were 600 companies in this sector that employed 80,000 employees. Thus, the proportions of the number of security staff in relation to the number of state security officers are different here than in the United States, because in the discussed period, there were 242 thousand policemen (state police, municipal police, and gendarmerie). (Widacki 1998, p. 71) In France, the activities of private security companies are governed by a law passed in 1983, according to which employees of these companies are obliged to wear uniforms with the emblem of this entity and carry a document confirming their identity during service. They cannot participate in situations caused by economic, political, racial or religious antagonisms (Johnston 1992. p. 80).

In Germany, the apogee for the development of private security companies took place in the 1990s. In 2000, the number of people employed in them amounted to 140,000 , which resulted in a conversion factor of 205 security employees per 100,000 inhabitants, while the same number included 321 policemen (ObergfellFuchs 2002, p. 680). In this country, there is no separate act defining the activities 
of the private security sector, which operates on the basis of general business regulations. No provision refers to the scope of tasks or rights held by employees, as they exercise the same rights as all citizens have. It is different in a situation where they provide protection for objects of strategic importance for the state. Then they have much wider powers.

The private security sector in Belgium is governed by the 1991 and pre-World War II laws of 1934 and 1936. In general, conducting this activity is unique and is permitted after obtaining special permission from the Ministry of the Interior. Private security companies are scarce, and 90 percent of 7,000 of their employees are employed by three companies. The Belgian police force has 15,000 officers. Under the regulations, owners of security companies submit reports to the Ministry of the Interior that controls their activities. They must also inform their local authorities about their undertakings and ensure security personnel clearly distinguish themselves from policemen (Johnston 1992, p. 90).

Moving away from Europe, it is worth noting the private security sector operating in Japan, which has become a permanent element of the security system of this country. Private security companies deal with the physical security of both private and state facilities, as well as escorting values, protecting mass events, and even managing traffic. Some of them specialise in providing technical security systems, especially monitoring. This type of activity is particularly popular and is distinguished by its very high technological advancement. The 90s was a period of particularly dynamic development of security companies. In 1994, there were 7,627 security companies, employing 342,357 employees in Japan, far more than the number of policemen. In that year, security guards arrested the perpetrators of 10,298 crimes, although the preventative factor, which consisted in preventing punishable acts, was definitely more important. It is significant that the vast majority of these employees did not have a licence. Only 30,091 people obtained this status through a decision of the public security commission operating in the prefectures. These employees clearly wore special identifiers confirming their rights in order to distinguish them from the ones without a license.

The situation that existed after the collapse of the Soviet Union is well illustrated by the example of one of the newly created states, Lithuania. The private security sector began to operate here with the country's political and economic autonomy. Three times fewer employees are employed in it than in the police, which has 
15,000 officers. The functioning of this sector is defined in detail by a legal act issued by the government in 1993 under the name "Statute for the safety of persons and property". It allows private protection company employees to carry a gun and use direct coercive means, provided they have obtained a licence from the Ministry of the Interior, which supervises their activities. It also specifies the conditions to be met by a candidate for a security employee. They must have Lithuanian citizenship, be over 25 years old and not appear in police files as a person with a mental disorder. They obtain a licence for a period of three years, after passing an examination in front of a commission of police officers. After the expiry of the indicated period, to retain their rights, they are required to re-pass the qualification exam (Speicys 1998, pp. 331-333).

Political and economic changes that began in Poland in the early 1990s caused not only acceleration of economic and civilisation processes ensuring dynamic progress and development in various areas of life, but also a sudden increase in crime and accompanying social pathologies. New types of crimes have appeared, including organised and international crimes. Poland's membership of the antiterrorist coalition and the participation of the Polish Armed Forces in both stabilisation missions and military operations abroad has created a real extremist threat for our country. A real problem emerged at that time for the state authorities: the means for effective resistance against these new challenges that result in an increased dynamic of the security threat. In this new situation, the state quickly realised that the existing, centralised security management was ineffective and did not correspond to the hitherto unknown threat determinants in Poland.

Private security companies stand as the third element of the public security system in Poland, after government and self-government administration. It is made up of private security companies, which in the literature on the subject are often called the private security sector. Another term for these formations is "private police". The latter indicates that we are dealing here with formations that are nonstate and private. Thus, there is a contradiction here. In the Police, officers are employed and act on behalf of and upon the authority of the state. In addition, according to art. 1 point 1a of the Act of 6 April 1990, "the Police" is a name reserved exclusively for the formation established on the basis of this Act. It is also worth remembering that the word police was taken from the Greek language "politheia", which originally meant the department of state administration, being 
a corps organised in a military model (Kawka 1939, p. 3). Hence, it seems more accurate to use the term "private security sector".

The results of the conducted research lead to the conclusion that the private security sector in countries with diverse political and economic systems is widely present and constitutes an important supplement to the governmental and selfgovernmental security system. There are countries such as: Austria, the Czech Republic, Germany, Israel, the United States and the United Kingdom where the legislation of these countries did not introduce any separate regulations ordering the functioning of this sector. In most countries. such legal acts appeared relatively recently, only in the 80 s and 90s. (Czapska 2002, p. 655). This indicates a different approach to the issue of defining the requirements and the scope of powers that a given country wants to give to the employees of the private security sector. In many countries, the state authority assumes that since the owners of private security companies, and often also employees, are mostly police officers and soldiers, it is enough for them to have contacts and experience to perform their tasks efficiently. This is quite a liberal approach, especially that security guards do not enjoy special privileges, but only the rights of all, regular, citizens. Actual cooperation with the police is not defined here by separate regulations, but results from social contacts built on the basis of a joint service. In the literature, this phenomenon is referred to as "blue drain". This provides the basis for the "oldboy's network", which can be translated as a network of veterans (Boon 1999, p. 196). In countries such as the United States, Belgium, France and the Netherlands, it is also common to employ police officers on active duty as security guards, who in this way conduct additional gainful activity. Unfortunately, this raises considerable legal doubts, as it is not very clear what kind of entitlements they should have at the time: police or dedicated to private security employees. Such a situation is inconsistent and may give rise to legal uncertainty and even doubts of a constitutional nature. It seems that a better solution is to separate legal laws and precisely define who can be a security worker, what selection criteria should be met, what the scope of their rights is and what powers and coercive measures they have while performing the tasks. Once these issues are clearly defined by the law, the risk of possible mistakes or fraud is less. The obligations of private security companies towards the state and the scope of mutual cooperation carried out within the public security system should be clearly defined. The situation is better when it results directly from the regulations and not only from customs or established practice. 
To assess the extent of private security sector participation in ensuring public security, the size of these structures is important in relation to the number of police officers employed in a given country. In this respect, as in cases related to legal regulations concerning the private security sector, there is considerable variation. As a rule, the number of policemen per 100,000 inhabitants is higher than the number of security personnel. For example: in Greece it is a ratio of 379 to 48, in Austria 318 to 69, in Belgium 356 to 96, in Finland 321 to 118, in Spain 458 to 183, in France 394 to 163, in Portugal 442 to 144 , in Ireland 304 to 145 , and in Italy 488 to 44 . However, there are countries in which these proportions are more advantageous in terms of quantity for the private sector. These include, for example, Hungary, where there are 298 police officers per 100,000 inhabitants and 532 security workers, the Czech Republic 471 to 481, the United Kingdom 318 to 344, Luxembourg 279 to 302, and Poland 265 to 518 (Obergfell-Fuchs 2002, p. 689).

\section{Security challenges}

Research indicates that in the 1990s, there was a sharp increase in crime, which in the former Warsaw Pact countries was primarily associated with political and economic transformation. The control of the state over citizens' activity was weakened, the first private fortunes were created, giving birth to the emergence of domestic capital. There was also an international transfer of funds and the borders became more open, also to the criminal world. New types of crime have appeared, including mafia-type organised crime. The state was no longer able to provide broadly understood security and this initiated a lasting change, which was the privatisation of public tasks. Societies also began, mainly thanks to the media, to feel an increased risk of a crime. In addition, ensuring security involved incurring large costs that the state no longer wanted to bear alone, especially that industrial plants and means of production systematically changed their ownership structure from state to private (cf. Czop 2012, pp. 83-84). In turn, the private sector of the economy and services was also directly interested in the protection of its property, which became a huge temptation for criminals. The private sector wanted to properly secure them, also giving adequate protection to itself and its clients. A significant role in the process of ensuring the increased security was played by insurance companies, which often, as a condition for ensuring 
compensation for losses incurred, demanded that appropriate equipment and physical protection or monitoring will be put to guard the facility, so it could reduce the risk of a criminal assault. Under these circumstances, the state decided to delegate some of its tasks, and thus also public security powers to private entities, and to newly established private security companies. Economic freedom, increased and aroused protection demand resulted in the creation of a new service sector that was supposed to deliver the goods, which was security itself. There are even views in the source literature that this is a manifestation of social inequalities due to the fact that those who can afford to pay for themselves or are simply able to buy a guarantee of security will be better protected. The less wealthy people had to continue to count on underfunded police only. In this way, crime was to move from the newly emerging wealthy districts to poorer regions (Czapska 2002, p. 650). This approach, however, seems too simplistic, as modern private security companies do not only protect private residences or their owners. Above all, they are present in the broadly considered space, where they fulfil an important preventive role, giving a sense of security to all people residing there, regardless of their social status. By taking responsibility for ensuring security in specific areas or facilities, they give the police the opportunity to become more involved in operational and investigative activities, in which state authorities can no longer be replaced. However, one should still bear in mind the fact that public security is first of all the responsibility of the state, which cannot release it. It is important to properly supervise the private security sector and create conditions for its best cooperation with the police to effectively integrate it into the public security system.

Terrorism is an imminent feature of modern civilisation. Terrorist attacks, in which many victims are killed, often accidentally, being civilians, can cause a destructive influence on the political and economic life of the state. Terrorism is a type of crime that equally affects people from the power apparatus as well as those who have nothing to do with politics. Terrorists, therefore, are considered as people who, in pursuing their motives and goals, commit crimes without looking at the multitude of victims or the massive damage they cause. Forecasts for the development of terrorism are not reassuring and specialists are afraid of its further escalation (Jałoszyński 2008, p. 31). Terrorism is a phenomenon that can shake the foundations of the functioning of the state, destabilising it economically and politically, which may give rise to an open armed conflict, and even war, as 
happened in 1914 after the attack in Sarajevo on the Austrian successor to the throne, Archduke Ferdinand (Sifakis 1994, p. 62).

There are crucial elements in the organisation of the state, the efficient functioning of which often depends on their existence. The destruction of such an element can contribute to the destruction of the entire organisation. Terrorism, destabilising economic centres and state management, may cause chaos in standard decisionmaking, causing social dissatisfaction and unrest against state power, perceived then as an organism weak and unable to control a crisis. The effects of terrorist attacks can be material, economic, legal, but also psychological, social and organisational, and from the time standpoint, immediate and long-term (Jałoszyński 2008, p. 32).

One of the issues, which was not observed on such a scale earlier in history, is Islamic terrorism that has assumed the quasi-state form of "ISIS", the so-called Islamic state in the Middle East. It seemed that the international terrorist activity of Al Qaeda, whose most spectacular success was the attack on the World Trade Center in New York and the headquarters of the Pentagon, is already the apogee of the threat of Islamic extremism. It turns out that a much greater danger arises with the creation of a self-proclaimed Islamic state whose primary goal is to export the Islamic revolution beyond the area in which it operates, i.e. the territory of war-torn Syria and Iraq. The terrorist attacks are inspired and carried out by the organisation in previously relatively safe countries of the European Union. The EU along with the US has become the main symbol of Western culture and civilisation, which, according to the assumptions of terrorists, must be destroyed as part of jihad (Czop and Piwowarski 2015). Another factor closely related to the threat posed by ISIS is the mass migration from war zones in the Middle East and Africa. The wave of migrants coming to the EU, especially Germany, is a phenomenon over which the governments of these countries and the entire European community has no control. Unfortunately, among those who flee from the nightmare of the war are their perpetrators who, making use of chaos, reach the countries that provide hospitality and humanitarian aid to the victims (ibid., p. 38-44). In these countries, a seemingly assimilated Muslim population appears to be radically re-Islamizing. This can result in attacks being carried out by citizens of these countries, descendants of Muslims who came there in the second and sometimes even the third generation (Czop and Czop 2016, p. 95-111). 


\section{Legislation and model of the private security sector in Poland}

In Poland, the key role in the creation of the private security sector has been played by the introduction of economic and political changes, and in particular the adoption of the Act on economic activity by the Polish Parliament on December 23, 1988 (Ustawa z dnia 23 grudnia 1988 r. o działalności gospodarczej, DzU nr 41, poz. 324 z późn. zm.). This legal act was the first regulation that anticipated running the activities in the sphere of security and property services. It introduced the obligation to obtain a licence to conduct security activities, as well as to provide detective services and passport matters. The amendment of this act in 1993 (Ustawa z dnia 16 grudnia 1993 r. o zmianie niektórych ustaw regulujących zasady opodatkowania i niektórych innych ustaw, DzU z 1993 r. nr 134, poz. 646) provided the legal basis for control over the companies. People employed in private security companies did not have any special rights then, only the socalled civil rights, that is, the right to defend, act in a state of higher necessity or civil detention. According to art. 734 pairs 2 of the Civil Code (Ustawa z dnia 23 kwietnia 1964 r. - Kodeks cywilny, DzU z 1964 r. nr 16, poz. 93) employees also received the so-called powers entrusted. The principle gave them the authority to perform specific activities, but only to the extent that they had. The security employee also had rights under art. 94 of the Labour Code (Ustawa $\mathrm{z}$ dnia 26 czerwca 1974 r. - Kodeks pracy, DzU z 1974 r. nr 24, poz. 141), which gave them the opportunity to require that the owner of the company familiarise them with the scope of duties, the manner of performing work, obliging the employers to guarantee compliance with the order and discipline of work. A person wishing to set up a personal and property security company had to obtain both a licence assigned by the Minister of the Interior and to inform the tax authorities about the start of operations. It was not until 1992 that the obligation to obtain a licence for the design, construction and maintenance of alarm systems was introduced. People employed in security companies did not have to have any licences or certificates in terms of having specific predispositions or skills. The owners of the companies only required that these people had good physical fitness and sometimes also a licence to possess a firearm. Such a situation meant that protection workers were often random, without proper professional training. The security companies tried to fill this gap by setting up their own training centres or 
using the services of emerging private training companies, in which, classes were usually conducted by former soldiers or police officers. In 1992, to govern the situation, a Team for the Review of Specialist Auxiliary Formations of Property and Order Protection was appointed by the Council of Ministers. (Komunikat z posiedzenia Rady Ministrów, maszynopis powielony, Warszawa, grudzień 1992 r.) The work of this Team was crowned with the preparation of a special report, which included a proposal to forward to the Minister of the Interior a draft of a separate act that would regulate the following issues:

- defining the scope of the protection of public and private property of special importance (generating a threat to people, the state and the environment) in relation to which a protection obligation would be required;

- defining the powers and means of direct coercion of security personnel, with particular emphasis on the use of firearms;

- indication of conditions regarding the licensing of the activities of private security companies;

- defining the scope and forms of state supervision over them;

- indication of the mode of creating one's own internal security services;

- defining the psychophysical qualifications and predispositions that candidates for security staff should answer. (Raport z prac Zespołu ds. Przeglądu Specjalistycznych Pomocniczych Formacji Ochrony Mienia i Porządku, maszynopis powielony).

In accordance with many reported cases of irregularities in the functioning of security companies, the Supreme Audit Office, in the period from June 1996 to February 1997, carried out audits of state authorities to determine whether they adequately supervised the functioning of these business entities. (Raport z kontroli NIK opracowany w 1997 roku, maszynopis powielony) The aim of the control activities was to determine the scope and forms of activity of private security companies and to diagnose whether the process of licensing their activities proceeds in accordance with legal requirements and whether state supervision is carried out in a reliable and effective manner, providing guarantees to protect public interests and individual citizens. The result of this inspection was an application to the Prime Minister for acceleration of activities aimed at precisely defining the rights and obligations of entities providing services in the sector of protection of people and property, so that they would guarantee effective protection of both the state and citizens' interests. The work was carried out by 
the government around creating the draft of an Act on the Protection of People and Property. The President of the Supreme Audit Office recognised such decisive action of the Council of Ministers as a correct response to a very critical report, which indicated that the functioning of private security companies in its current form posed a threat to human rights and should not be taking place in a democratic state of law. (Diariusz Sejmowy z 112 posiedzenia Sejmu w dniu 29 lipca 1997 ) The governmental bill was sent to the Sejm, where the discussion on the proposed regulations intensified. During the meeting of the combined Justice and Human Rights and Administration and Home Affairs committees, it appeared that it was paradoxical that the Police in their activities was strictly limited by law, and the security company, often acting only in the private interest, had a much wider scope of possible actions. No law regulated the exact scope and form of their operation. This freedom and the lack of normative restrictions could and did endanger the protection of civil rights, which after all benefitted from constitutional guarantees. Therefore, to protect these interests, there should be a precise definition of the scope of security companies' rights. Defining these prerogatives should take place in the form of the Act, because the rights to interference with civil liberties were to be determined (ibid.) In the discussion, the Ministry of the Interior pointed out that the Act on Economic Activity did not define the concept of personal and property protection services at all. Thus, the state de facto regulated an area that was unknown. In addition, only physical security services were licensed even though technical protection might give rise to similar risks if carried out in an uncontrolled manner. At that time, technical protection was outside the sphere of any legal regulations. Representatives of the National Union of Person, Property Protection and Detection Services emphasised that the companies associated with it were also vitally interested in enacting the law and introducing licenses that would only allow the best candidates to perform the profession of security guard, thus excluding people without proper preparation and not meeting the psychophysical criteria. This solution would also ensure a good reputation for companies providing services in the area of protection of people and property (Biuletyn Komisji Sejmowych nr 3719/II z 17 czerwca 1997). Thus, both the state authorities and the economic self-government of the security sector recognised that the creation of the Act on the protection of people and property was a matter of priority, which required quick proceedings. This determination in pursuit of the legal ordering of matters related to the private security sector resulted in 
the adoption, on 22 August 1997, of the Act on the Protection of Persons and Property (Ustawa z dnia 22 sierpnia 1997 r. o ochronie osób i mienia, DzU z 1997 r. nr 114, poz. 740). The state administration, responsible for the state security system, recognised that its partner at the local level must be entrepreneurs meeting high requirements and employing employees with appropriate professional qualifications, especially that the new law gave them a number of rights, which were previously available only to public officials. According to the provisions of the cited Act, protection of persons should be understood as measures aimed at ensuring the safety of life, health and personal inviolability (Franklin 2011, p. 5). On the other hand, property protection has been defined as actions preventing crimes and offences against property, as well as counteracting the occurrence of damage resulting from these events and preventing unauthorised persons from entering the protected area. According to the Act, protection of people and property is carried out in the form of direct physical protection, which may be permanent or temporary (Hanausek 1998, p. 12-14). It can consist of constant supervision of signals sent, collected and processed in electronic devices and alarm systems or on escorting monetary values and other valuable or dangerous objects. It can also be implemented by means of technical security, consisting of assembly of electronic devices and alarm systems, signaling the threat of protected people and property, as well as operation, maintenance and repairs in places where those are installed. The assembly of devices and means of mechanical protection as well as their operation, maintenance, repair and emergency opening in the installation places are also considered to be this type of security (Nowicki 1999, p. 135).

The use of direct coercion measures and firearms, and documenting this use, are carried out under the terms of the Act of 24 May 2013 on measures of direct coercion and firearms (Ustawa z dnia 24 maja 2013 r. o środkach przymusu bezpośredniego i broni palnej, DzU z 2013 r., poz. 628).

Specialist armed security formations are essential for ensuring security in places that are of strategic importance for the functioning of the state and are therefore subject to mandatory protection. In the field of state defence, the areas, facilities, equipment and transport which are subject to mandatory protection include, in particular: special production plants and plants in which scientific research or construction work is carried out in the scope of such production, plants manufacturing, repairing and storing armaments, military equipment 
and strategic reserve stores (Ustawa z dnia 29 października 2010 r. o rezerwach strategicznych, DzU nr 229, poz. 1496, art. 15). In terms of protection of the economic interest of the state, there are, in particular, facilities directly related to the mining of strategic minerals for the state, seaports and airports, banks and enterprises producing, storing or transporting monetary values in significant quantities. In the field of importance of public security, facilities, plants and devices of significant importance for the functioning of urban conurbations were recognised as such, destruction or damage to which may pose a threat to human life and health and the environment, in particular, power plants and heat plants, water intakes, waterworks and sewage treatment plants. These are also establishments using, producing or storing in considerable quantities, nuclear materials, sources and radioactive waste, toxic, narcotic, explosive or chemical substances with high fire or explosive compliance, as well as fuel pipelines, power and telecommunications lines, dams and sluices, and other devices located in an open area, that destruction or damage to could endanger human life or health, the environment or cause serious material damage (cf. Horak 2012).

Considering the criterion of protection of state interests other than those indicated above, these are, in particular, plants with unique economic production, telecommunications, postal, television and radio facilities, museums and other facilities in which national cultural goods and the state archives are collected.

Detailed lists of areas, facilities and equipment referred to in art. 5 para. 2 of the Act on the Protection of People and Property are prepared by the President of the National Bank of Poland, the National Council of Radio Broadcasting and Television, ministers, heads of central offices and provinces (called voivodeships in Poland) in relation to subordinate or supervised organisational units. Listing of a specific area, facility or device is always done by means of an administrative decision. These lists are sent by the above authorities to territorially competent voivodeships and they are updated on an ongoing basis. In accordance with their territorial jurisdiction, they keep records of areas and facilities which are subject to mandatory protection. It is confidential, but the information that a given area, object or device is subject to mandatory protection has the status of full disclosure. Voivodes may also place in their records, the areas, facilities and equipment of entities other than those which are directly indicated in the quotation of the Act. 
As noted earlier, transport is also subject to compulsory protection in certain situations. For such demanding protection, the legislator considered the transport of weapons, ammunition, explosives and military equipment sent from areas and facilities that are subject to mandatory protection.

Thus, areas, facilities, equipment and transport important for defence, the economic interest of the state, public security and other important state interests are subject to mandatory protection by specialist armed protective formations or appropriate technical protection. In the course of the research, it was found that the optimal solution and the most commonly used in practice is the simultaneous application of both of the above-mentioned forms of protection (Wiłun 2005, p. 106). Such particular solutions, imposed by the legislator, in the field of ensuring the safety of facilities which are subject to mandatory protection, and especially the requirement of arms, are justified, in particular in a situation of increased terrorist threat.

\section{Conclusions}

According to the author, the role of adequate preventive protection, the antiterrorist protection of the strategic centres for the state and its economy, is very important. In practical terms, it is conducted by specialist armed protective formations (Kaczyński 2009, p. 18-32). It was with this type of security company that the state set normative rules for cooperation, defining them in the Regulation of the Ministry of Internal Affairs and Administration of December 18, 1998 on defining detailed rules for cooperation between SUFO and the Police, fire protection units, civil defense and municipal guards (Rozporządzenie Ministra Spraw Wewnętrznych i Administracji z dnia 18 grudnia 1998 r. w sprawie określenia szczegółowych zasad współpracy specjalistycznych uzbrojonych formacji ochronnych z Policją, jednostkami ochrony przeciwpożarowej, obrony cywilnej i strażami gminnymi (miejskimi), DzU z 1998 r., nr 161, poz. 1108). According to the author, similar regulations should appear in relation to companies from the private security sector other than SUFO. To optimise the cooperation process, it should include not only the Police, Municipal Police, Fire Brigade or Civil Defence, but other uniformed formations responsible for security 
in Poland. It has been observed that legal provisions organise such cooperation and specify the framework in which it should take place. The author expresses the view that the international situation implying the increase of the threat should lead the legislator to take intensive actions to integrate elements constituting the security system, of which the private security sector is an essential part. Without it, it would be difficult to imagine effective public security, which before the economic and political transformation was the exclusive domain of the state, constituting its monopoly. At present, the state has retained responsibility for the state of security as its important duty, but has shared responsibilities in this area with commercial entities. The analysis made it possible to answer specific research questions, and consequently gave a positive answer to the main research question. The author thus showed the importance of security companies as a part of the public security system in Poland. The conducted research process clearly shows that the tendency for greater involvement of the private security sector in activities aimed at securing the critical infrastructure of the state should be constantly strengthened and developed.

\section{References}

Biuletyn Komisji Sejmowych nr 3719/II z 17 czerwca 1997 r.

Boon, K., 1999. La function d'enquetedans le secteurprive. In H. S. Becker (ed.), Deviance et societe, Berkeley.

Czapska, J., 2002. Prywatne firmy ochrony osób i mienia w Europie - podstawowe problemy prawne. In J. Czapska and H. Kury (eds), Mit represyjności albo o znaczeniu prewencji kryminalnej, Kraków.

Czop, A. and Czop, P., 2016. Konieczność kompleksowych i interdyscyplinarnych działań na rzecz współczesnego bezpieczeństwa w kontekście sektorowości zagrożeń. In Kultura Bezpieczeństwa. Nauka - Praktyka - Refleksje, 22, Kraków.

Czop, A., Piwowarski, J., 2015. Aktualne ruchy migracyjne jako czynnik zagrożenia terrorystycznego w Europie i w Polsce. Szczytno.

Czop, A., 2012. System bezpieczeństwa publicznego w Polsce. In W. Hrynicki and J. Piwowarski (eds), Kultura Bezpieczeństwa. Nauka - Praktyka - Refleksje, 12, Kraków.

Diariusz Sejmowy z 112 posiedzenia Sejmu w dniu 29 lipca 1997 r.

Franklin, M. J., 2011. How to Protect Others. New York.

Hanausek, T., 1998. Ustawa o ochronie osób i mienia. Komentarz. Torun.

Horak, K., 2012. The New Bodyguard. Natley Hall, United Kingdom. 
Kaczyński, J., 2009. Taktyka działań ochronnych. Ochrona osób. Gdańsk.

Jałoszyński, K., 2008. Wspótczesny wymiar antyterroryzmu. Warszawa .

Johnston, L., 1992. The Rebirth of Private Policing. New York.

Kawka, W., 1939. Policja w ujęciu historycznym i wspótczesnym. Wilno.

Komunikat z posiedzenia Rady Ministrów, maszynopis powielony, Warszawa, grudzień 1992.

Maslow, A., 2009. Motywacja i osobowość. Warszawa.

(MINI)SŁOWNIK BBN: Propozycje nowych terminów z dziedziny bezpieczeństwa. [online].Availablefrom:http://www.bbn.gov.pl/pl/bezpieczenstwo-narodowe/minislownikbbn-propozy/6035,MINISLOWNIK-BBN-Propozycje-nowych-terminow-z-dziedzinybezpieczenstwa.html [Accessed 15 Oct 2017].

Nowicki, T., 1999. Ochrona osób i mienia. Toruń.

Obergfell-Fuchs, J., 2002. O znaczeniu prywatnych firm ochrony osób i mienia w Niemczech. In J. Czapska and H. Kury (eds), Mit represyjności albo o znaczeniu prewencji kryminalnej. Kraków.

Pieprzny, S., 2012. Administracja bezpieczeństwa i porządku publicznego. Rzeszów. [online]. Available from:

http://www.Public-policy.org [Accessed 15 Oct 2017].

Raport z kontroli NIK opracowany w 1997 roku, maszynopis powielony.

Raport z prac Zespołu ds. Przeglądu Specjalistycznych Pomocniczych Formacji Ochrony Mienia i Porządku, maszynopis powielony.

Rozporządzenie Ministra Spraw Wewnętrznych i Administracji z dnia 18 grudnia 1998 r. w sprawie określenia szczegółowych zasad współpracy specjalistycznych uzbrojonych formacji ochronnych z Policją, jednostkami ochrony przeciwpożarowej, obrony cywilnej i strażami gminnymi (miejskimi), DzU z 1998 r., nr 161 poz. 1108.

Sifakis, C., 1994. Encyklopedia zamachów. Warszawa-Kraków.

Speicys, R., 1998. Prywatne firmy ochroniarskie na Litwie. In J. Widacki and J. Czapska (eds), Bezpieczny obywatel - bezpieczne państwo. Redakcja Wydawnictw KUL, Lublin.

Ustawa z dnia 23 grudnia 1988 r. o działalności gospodarczej, DzU nr 41, poz. 324 z późn. zm.

Ustawa z dnia 23 kwietnia 1964 r. - Kodeks cywilny, DzU z 1964 r., nr 16, poz. 93.

Ustawa z dnia 26 czerwca 1974 r. - Kodeks pracy, DzU z 1974 r., nr 24, poz. 141.

Ustawa z dnia 22 sierpnia 1997 r. o ochronie osób i mienia, DzU z 1997 r., nr 114, poz. 740.

Ustawa z dnia 29 października 2010 r. o rezerwach strategicznych, DzU nr 229, poz. 1496.

Ustawa z dnia 24 maja 2013 r. o środkach przymusu bezpośredniego i broni palnej, DzU z 2013 r., poz. 628 .

Ustawa z dnia 16 grudnia 1993 r. o zmianie niektórych ustaw regulujących zasady opodatkowania i niektórych innych ustaw, DzU z 1993 r., nr 134, poz. 646.

Widacki, J., 1998. Ustrój i organizacja Policji w Polsce oraz jej funkcje i zadania w ochronie bezpieczeństwa i porząku. Warszawa-Kraków. 
Widacki, J. and Sarnecki, P., 1997. Ustrój i organizacja Policji w Polsce oraz jej zadania w ochronie bezpieczeństwa i porządku. Warszawa-Kraków.

Wiłun, K., 2005. Ochrona osób i mienia. Organizacja i przygotowanie specjalistycznych uzbrojonych formacji ochronnych do działań w systemie obronności państwa. BielskoBiała 2005.

Wyrok Sądu Najwyższego z 22 grudnia 1993 r., I KZP 30/93, OSNKW, 1994 r., nr 1-2, poz. 6. 